Article

\title{
Synthesis and Characterization of Novel Polythiophenes Containing Pyrene Chromophores: Thermal, Optical and Electrochemical Properties
}

\author{
Bianca X. Valderrama-García ${ }^{1}$, Efraín Rodríguez-Alba ${ }^{1}$, Eric G. Morales-Espinoza ${ }^{1}$, \\ Kathleen Moineau Chane-Ching ${ }^{2,3, *}$ and Ernesto Rivera ${ }^{1, *}$ \\ 1 Instituto de Investigaciones en Materiales, Universidad Nacional Autónoma de México, \\ Circuito Exterior Ciudad Universitaria, Mexico City 04510, Mexico; biancaxvg@msn.com (B.X.V.-G.); \\ efrainhelio@gmail.com (E.R.-A.); erichsm536@yahoo.com.mx (E.G.M.-E.) \\ 2 Centre National de la Recherche Scientifique (CNRS), Laboratoire de Chimie de Coordination (LCC), \\ 205, Route de Narbonne, Toulouse F-31077, France \\ 3 Institut National Polytechnique, Université de Toulouse, Université Paul Sabatier, Toulouse F-31077, France \\ * Correspondence: kathleen.chane@lcc-toulouse.fr (K.M.C.-C.); riverage@unam.mx (E.R.); \\ Tel.: +33-561-33-31-33 (K.M.C.-C.); +52-55-56-22-47-33 (E.R.)
}

Academic Editors: Scott Reed and Marino Resendiz

Received: 14 December 2015; Accepted: 25 January 2016; Published: 30 January 2016

\begin{abstract}
A novel series of pyrene containing thiophene monomers TPM1-5 were synthesized and fully characterized by FTIR, MS, ${ }^{1} \mathrm{H}$ - and ${ }^{13} \mathrm{C}-\mathrm{NMR}$ spectroscopy; their thermal properties were determined by TGA and DSC. These monomers were chemically polymerized using $\mathrm{FeCl}_{3}$ as oxidizing agent to give the corresponding oligomers TPO1-5) and they were electrochemically polymerized to obtain the corresponding polymer films deposited onto ITO. All oligomers exhibited good thermal stability, with $\mathrm{T}_{10}$ values between 255 and $299^{\circ} \mathrm{C}$, and $\mathrm{T}_{\mathrm{g}}$ values varying from 36 to $39^{\circ} \mathrm{C}$. The monomers showed an absorption band at $345 \mathrm{~nm}$ due to the $\mathrm{S}_{0} \rightarrow \mathrm{S}_{2}$ transition of the pyrene group, whereas the fluorescence spectra showed a broad emission band arising from the "monomer" emission at $375-420 \mathrm{~nm}$. The obtained polymers exhibited two absorption bands at 244 and $354 \mathrm{~nm}$, due to the polythiophene and the pyrene moieties, respectively. The fluorescence spectra of polymers showed a broad "monomer" emission at 380-420 nm followed by an intense excimer emission band at $570 \mathrm{~nm}$, due to the presence of intramolecular pyrene-pyrene interactions in these compounds.
\end{abstract}

Keywords: polythiophene; pyrene; electrosynthesis; absorption; fluorescence

\section{Introduction}

In recent years, the synthesis and characterization of polymers containing heteroaromatic rings have been widely studied because of their potential in advanced optoelectronic applications [1-5] Polythiophene (PT) has been considered one of the most promising $\pi$-conjugated polymers due to its high stability, ease of structural modification and controllable optical and electrochemical properties. At the beginning the applications of non-substituted polythiophene were very limited because of its insolubility in many organic solvents, due to its extended $\pi$-conjugated structure. Furthermore, alkyl chains have been incorporated into the thiophene units in order to obtain functional monomers able to yield soluble polymers. The poly(3-alkylthiophene)s resulted to be highly processable conducting polymers, whose solubility allowed their full characterization by spectroscopic methods [6]. The stability of poly(3-alkylthiophene)s in the doped state can be performed by introducing alkoxy chains. The incorporation of alkoxy groups into polythiophenes increases significantly their conductivity without decreasing their solubility in many organic solvents $[7,8]$. 
Most polythiophenes exhibit interesting optical properties such as thermochromism [9-11], ionochromism [10-12], photochromism [13], piezochromism [14] and biochromism [15]. Colour changes are mainly due to transitions from planar to twisted conformation of the polymer backbone and vice versa, which modifies the conjugation length, thereby causing a shift of the absorption bands in their UV-vis spectra [16]. In polymers containing alkoxy groups at 3-position of the thiophene rings, the lone pairs of the oxygen atom enter into conjugation with the polythiophene backbone, inducing a planar conformation, electronic mobility and a higher conductivity [17].

The chromic properties of substituted polythiophenes make them excellent prospects for light emitting diodes [18], gas sensors [19-21], biomedical applications [22], metal ions sensors [23,24], biosensors [25-28], and other related applications [29-31].

On the other hand, pyrene is a very useful fluorescent probe which has been widely employed for polymer labeling because it easily forms excimers. Moreover, pyrene exhibits a longer singlet lifetime than other chromophores, which favors the formation of excimers. The main photophysical properties of pyrene excimers have been discussed in detail by Winnik [32]. An excimer emission band appears if a pyrene molecule in the excited state associates with another in the ground state, after which a photon is delocalized over the conjugate to show a net change in the fluorescence spectrum profile. The resulting optical and photophysical properties provide us useful information about the molecular geometry, internal stacking of the pyrene groups and polymer interactions at long distance.

In our research group, we have synthesized and characterized a wide variety of $\pi$-conjugated polymers and oligomers containing pyrene units in their structure. We studied the effect of the internal stacking of the pyrene groups on the optical and photophysical properties [33-37]. Very recently, we carried out the incorporation of pyrene moieties into polythiophenes in order to obtain donor-acceptor systems for optical applications [29-31,38,39]. These polymers can be synthesized either by chemical or electrochemical methods. In fact, the electropolymerization offers many advantages over other synthetic approaches, such as the absence of catalyst, a direct deposition of a doped polymer film onto the electrode surface, in situ characterization and easy control of the thickness of the deposited film [14].

In this work, we report the synthesis and characterization of a novel series of thiophene monomers TPM1-5 containing pyrene units and alkyl spacers linked by an ester group (Figure 1), which were chemically polymerized to give the corresponding oligothiophenes (Figure 2) and electrochemically polymerized to form polythiophenes (Figure 3). Monomers were fully characterized by FTIR, MS-CI, ${ }^{1} \mathrm{H}$ - and ${ }^{13} \mathrm{C}-\mathrm{NMR}$ spectroscopy. In TPM1 the carbonyl group is directly attached to the pyrene unit, in TPM5 to the thiophene ring and in the other monomers (TPM2, TPM3 and TPM4) the ester function is located in the middle of the flexible spacer, in order to study the effect of the position of the carbonyl group on the optical and electronic properties. The thermal properties were determined by TGA and DSC, and the optical properties were studied by UV-Vis and fluorescence spectroscopy. Regarding the oligomers, these compounds were characterized by MALDI-TOF, and their thermal properties were analyzed by TGA and DSC. Unfortunately, it was not possible to characterize them by NMR in solution because they resulted to be insoluble in many organic solvents, which can be due to the presence of the pyrene units that undergo the formation of aggregates. A similar behavior has been observed in other polymers with high pyrene content $[38,40]$. Concerning the electrochemically obtained polymers, they were studied by cyclic voltammetry in order to determine their oxidation and polymerization potentials. The optical properties of the obtained polythiophenes were studied by absorption and fluorescence spectroscopies in solid state. Due to their chromic properties, pyrene's ability to form excimers and oxygen sensitivity, these oligomers and polymers can be used as sensors or as luminescent materials in OLEDs [41-43]. 

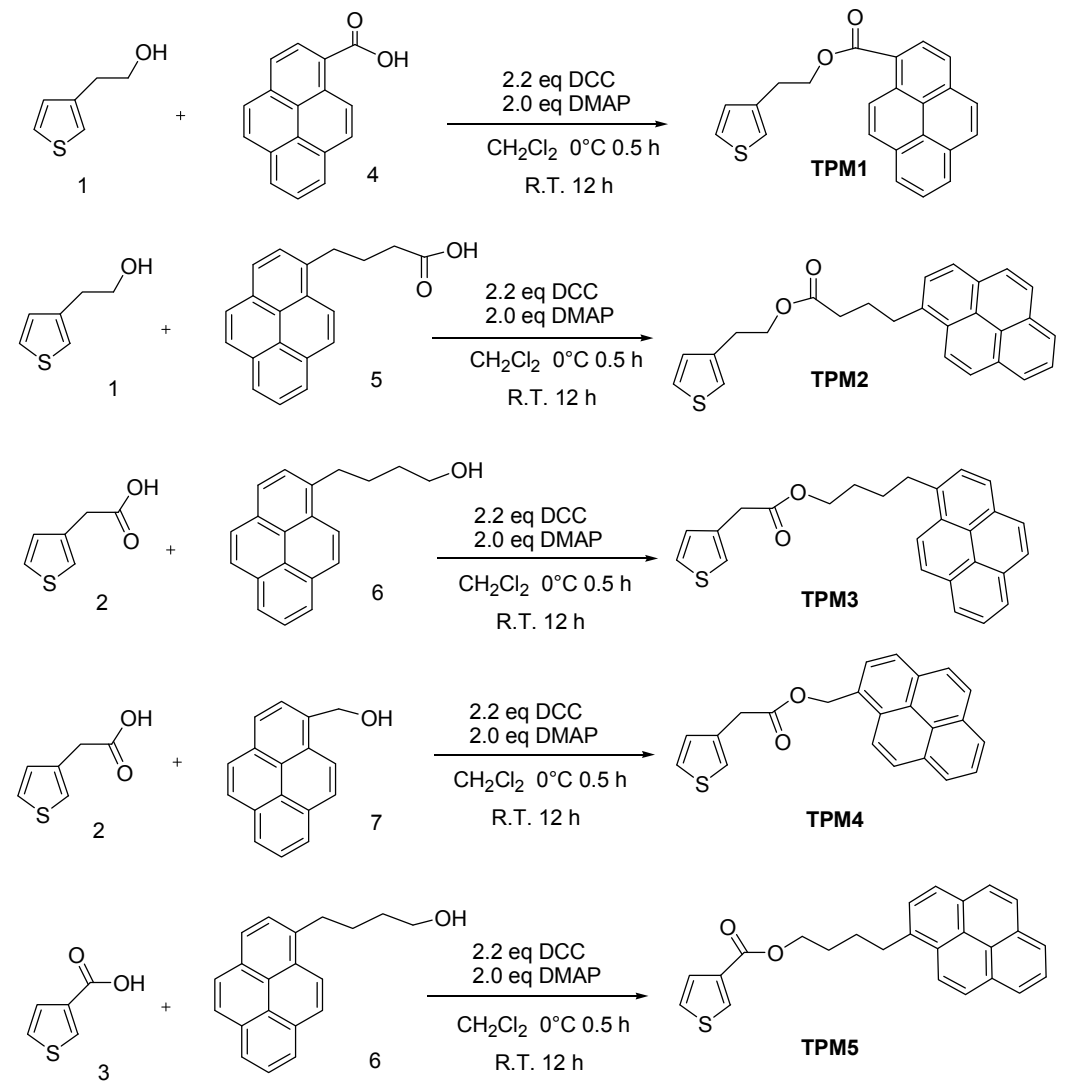

Figure 1. Synthesis of thiophene monomers containing pyrene groups.

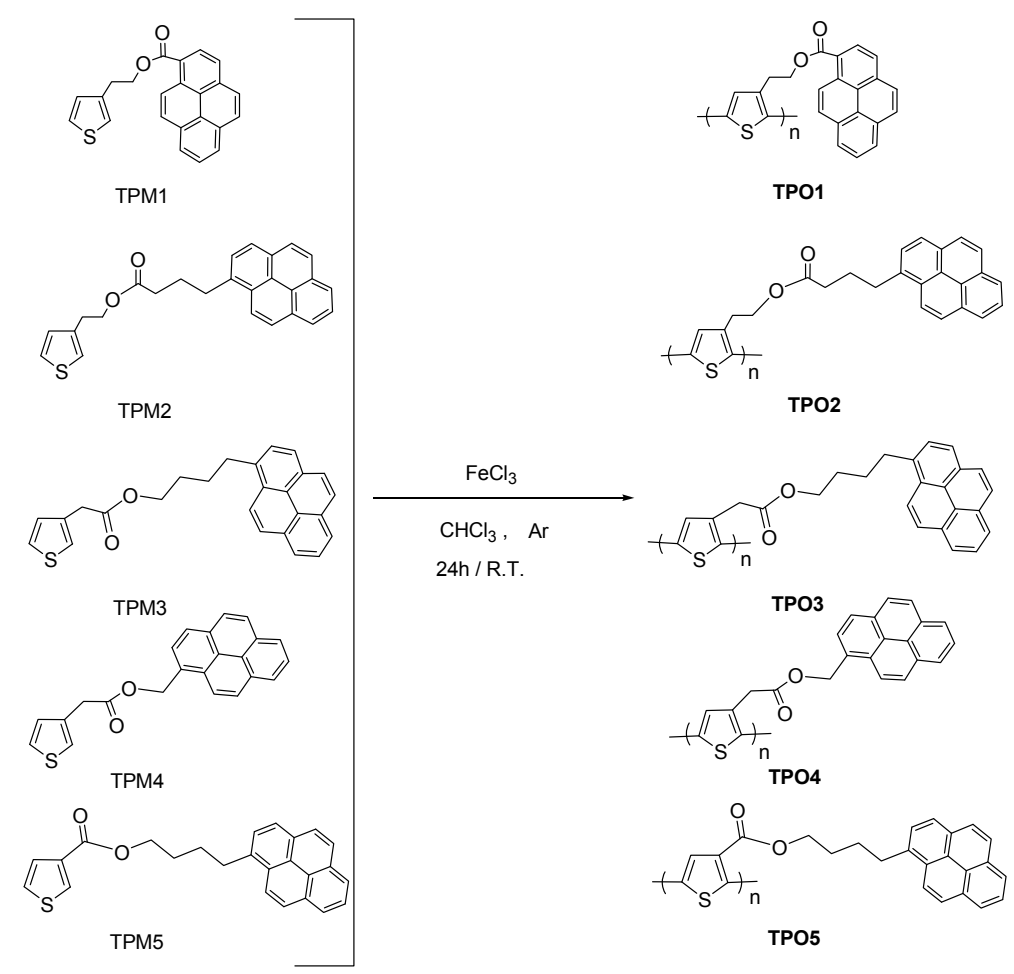

Figure 2. Synthesis of the obtained oligothiophenes, where the n values for TPO1-TPO5 are 6, 8, 6, 5, and 8 respectively. 


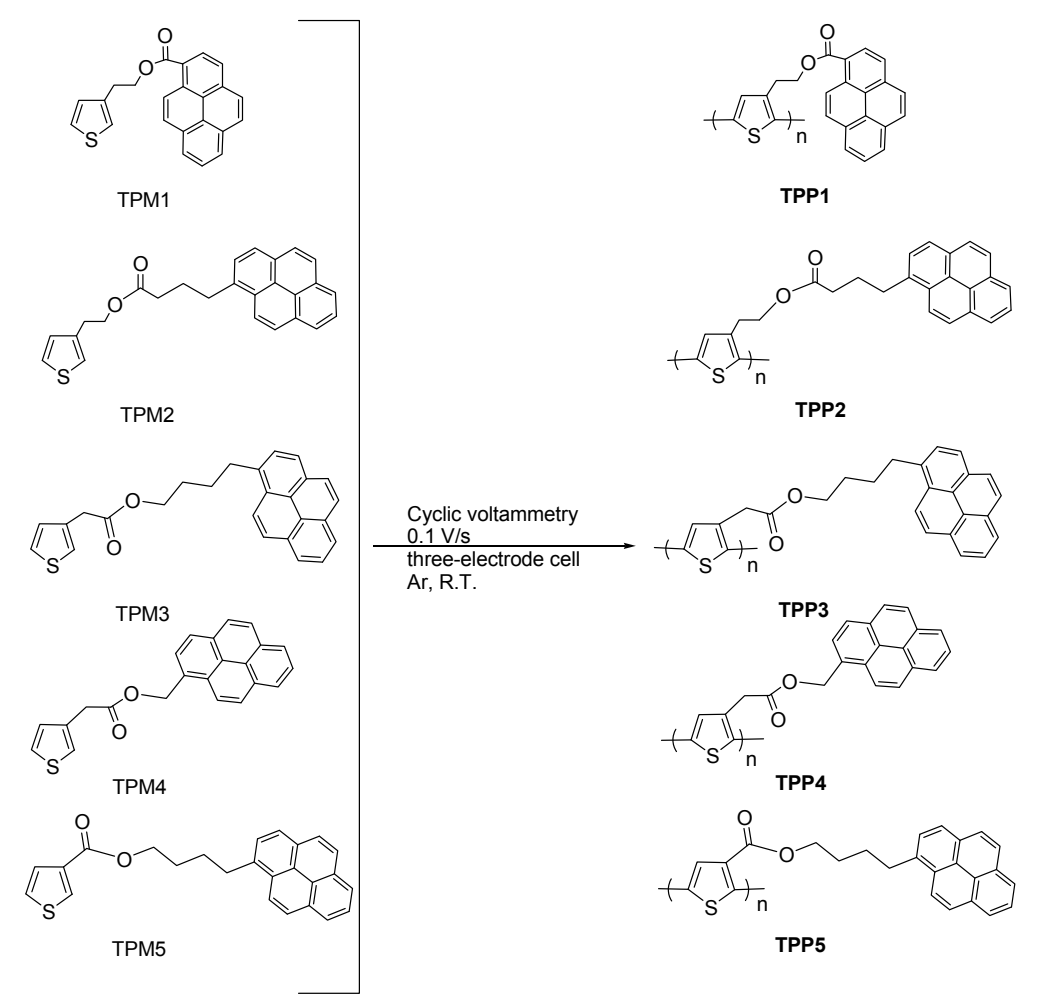

Figure 3. Electrochemical synthesis of polythiophenes containing pyrene units.

\section{Results and Discussion}

\subsection{Spectroscopical Characterization}

The obtained monomers were characterized by FTIR and NMR spectroscopies. In the FTIR spectra of these compounds (Figure 4), we can observe two bands at 3106 and $3026 \mathrm{~cm}^{-1}$ due to the C-H bonds of the pyrene unit and the thiophene ring, respectively. Moreover, we can perceive two bands at 2930 and $2850 \mathrm{~cm}^{-1}$ due to asymmetric vibration of $\mathrm{CH}_{2}$ groups, as well as another band at $1723 \mathrm{~cm}^{-1}$ attributed to the $\mathrm{C}=\mathrm{O}$ bond (stretching) of the ester, followed by a band at $1643 \mathrm{~cm}^{-1}$ corresponding to $\mathrm{C}=\mathrm{C}$ bonds of the aromatic rings. In addition, we can see two bands at 1255 and 1197 due to $\mathrm{C}-\mathrm{O}$ bond of the ester. Finally, two prominent bands at 838 and $742 \mathrm{~cm}^{-1}$ arising from C-H (out of plane) were also observed.

The ${ }^{1} \mathrm{H}-\mathrm{NMR}$ spectra of monomers in $\mathrm{CDCl}_{3}$ solution are shown in the Supplementary Materials (Schemes S1-S5 in Supplementary Materials). As we can see, all spectra show a multiplet at ca. 7.85-9.20 ppm, due to the protons of the pyrene unit, followed by a double doublet at $7.51 \mathrm{ppm}$ with $J=4.6 \mathrm{~Hz}$ assigned to proton $\mathrm{H}^{5}$ of the thiophene ring. A doublet at $7.21 \mathrm{ppm}$, attributed to proton $\mathrm{H}^{2}$ with $J=4.7 \mathrm{~Hz}$ and a double doublet at 7.04 with $J=4.9 \mathrm{~Hz}$ corresponding to proton $\mathrm{H}^{4}$ of thiophene were also observed. In the aliphatic region, we can perceive the signals due to protons of the $\mathrm{CH}_{2}$ groups of the aliphatic segment and those arising from the protons of $\mathrm{OCH}_{2}$ groups, which appear between 3-4 ppm.

In the ${ }^{13} \mathrm{C}$-NMR spectra of monomers, we can notice four signals at 155, 138, 118 and $96 \mathrm{ppm}$, due to carbons of the thiophene ring $C^{2}, C^{3}, C^{4}$, and $C^{1}$, respectively. In the aromatic region, we observed the signals corresponding to carbons of pyrene unit (16 carbons), which appeared between 134-120 ppm. The signal of $\mathrm{OCH}_{2}$ protons can be seen at $65 \mathrm{ppm}$, as well as a series of peaks between 28-36 ppm attributed to the methylene groups $\mathrm{CH}_{2}-\mathrm{CH}_{2}$ of the aliphatic chain.

All monomers were chemically polymerized using $\mathrm{FeCl}_{3}$ as oxidizing agent to give the corresponding oligomers and electrochemically polymerized to give a series of polymers, which 
were characterized by FTIR. The polymerization reaction conditions are described in the experimental section. The FTIR spectra of TPM5, TPO5, and TPP5 are illustrated in Figure 4. The polymerization was confirmed by FTIR spectroscopy; the obtained oligomers and polymers exhibited the same bands as their precursor monomers. However, we can observe a decrease in intensity of the bands at 3106 and $3026 \mathrm{~cm}^{-1}$ due to the disappearance of the $\mathrm{C}-\mathrm{H}$ bonds present in the thiophene ring of the monomer to form the new $\mathrm{C}-\mathrm{C}$ bonds of the polymer, which confirmed that the polymerization reaction took place. Moreover, the bands at 838 and $742 \mathrm{~cm}^{-1}(\mathrm{C}-\mathrm{H}$, out of plane) diminished in intensity.

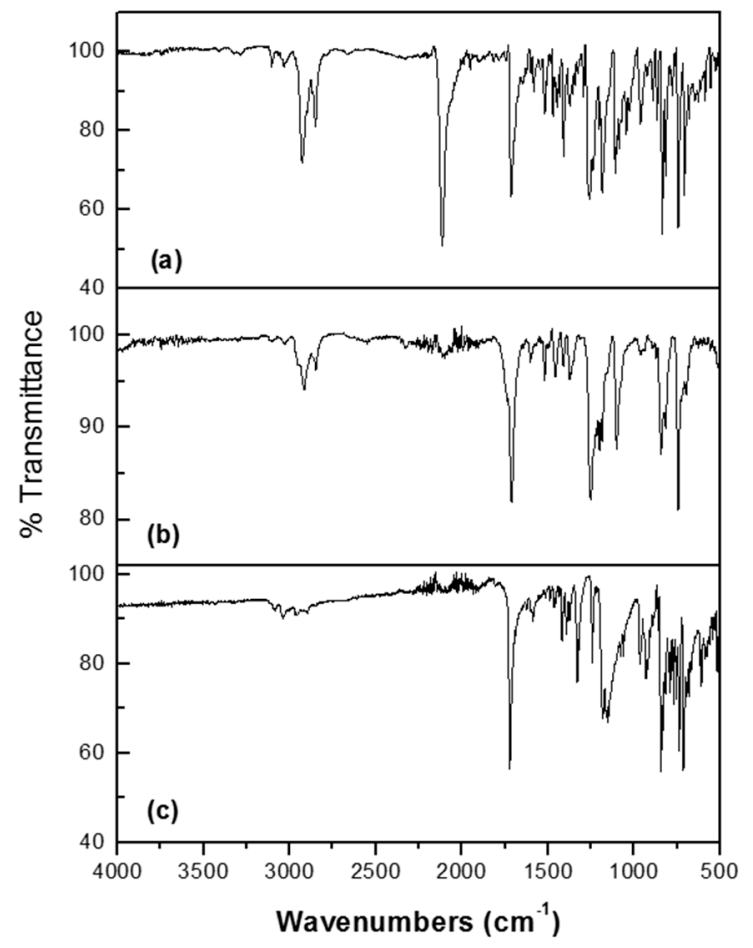

Figure 4. FTIR spectra (a) monomer TPM5; (b) oligomer TPO5 and (c) polymer TPP5.

\subsection{Thermal Properties}

The thermal stability of the compounds was determined by thermogravimetric analysis (TGA). The melting point as well as the glass transition temperature $\left(\mathrm{T}_{\mathrm{g}}\right)$ were measured with a Differential Scanning Calorimeter (DSC). The thermal properties of monomers and oligomers are summarized in Table 1.

Table 1. Thermal properties of monomers and oligomers.

\begin{tabular}{ccccccc}
\hline Compound & m.p. $\left({ }^{\circ} \mathbf{C}\right)$ & Compound & m.p. $\left({ }^{\circ} \mathbf{C}\right) / \mathbf{T}_{\mathbf{g}}\left({ }^{\circ} \mathbf{C}\right)$ & $\mathbf{T}_{\mathbf{1 0}}\left({ }^{\circ} \mathbf{C}\right)$ & Degradation $\left({ }^{\circ} \mathbf{C}\right)$ & $\% \mathbf{W}_{\mathbf{t}}$ Remaining \\
\hline TPM1 & 117.6 & TPO1 & $>250 / 38.0$ & 292.6 & $310-348$ & 3.33 \\
TPM2 & 66 & TPO2 & $>250 / 36.0$ & 299.3 & $310-330$ & 12.16 \\
TPM3 & 83.3 & TPO3 & $>250 / 39.1$ & 272.7 & $277-347$ & 12.14 \\
TPM4 & 67.7 & TPO4 & $>250 / 36.1$ & 255.9 & $260-315$ & 38.71 \\
TPM5 & 96 & TPO5 & $>250 / 37.9$ & 273.2 & $313-374$ & 4.659 \\
\hline
\end{tabular}

Concerning the melting points of the monomers, we can notice that the melting point of TPM1 is higher than that of the others compounds, this might be due to a structural arrangement or stacking of the pyrene units, which provides higher crystallinity to the molecule. In the case of the oligomers, we can observe that their $\mathrm{T}_{\mathrm{g}}$ values are very similar (between 36 and $39^{\circ} \mathrm{C}$ ), and they are thermally stable above $250^{\circ} \mathrm{C}$. 
TGA thermograms of the obtained oligomers are shown in Figure 5. The decomposition profile of these compounds are very similar to that reported for polythiophene itself [44], leaving between 3.3-38.7 wt \% of remains after having heated up to $400{ }^{\circ} \mathrm{C}$. This can be due to the rigidity of the TPO1- 5 backbone. The thermograms exhibited drastic degradation above $260{ }^{\circ} \mathrm{C}$ with $\mathrm{T}_{10}$ values between $256-299^{\circ} \mathrm{C}$. Similarly, TPO1 and TPO2 resulted to be thermally more stable with $\mathrm{T}_{10}$ values between $293-299^{\circ} \mathrm{C}$, showing degradation beyond $300^{\circ} \mathrm{C}$.

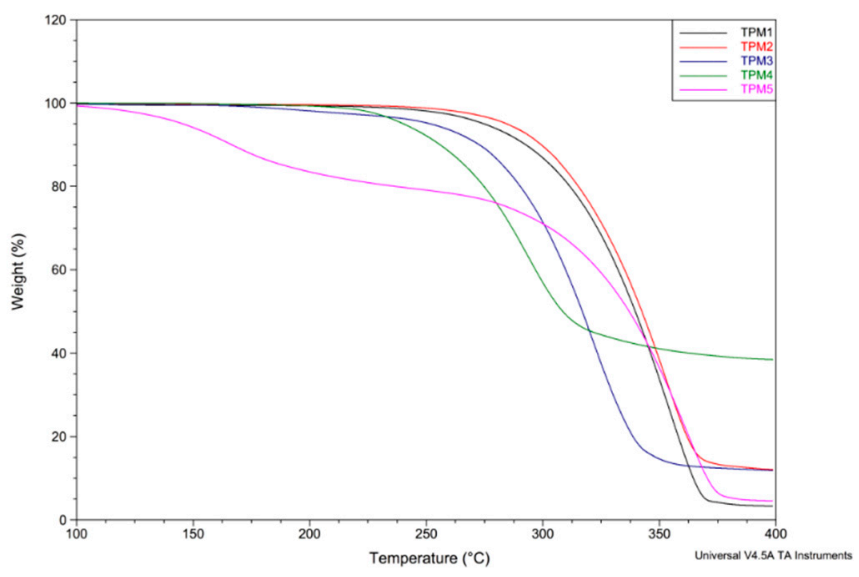

Figure 5. TGA curves of the oligomers TPO1-5.

\subsection{Optical Properties of the Monomers}

The optical properties of the monomers were studied in fresh $\mathrm{CH}_{2} \mathrm{Cl}_{2}$ solution by absorption and fluorescence spectroscopy; the results are summarized in Table 2. The UV-vis and fluorescence spectra of the monomers are shown in Figures 6 and 7 respectively. It has been verified that the Beer-Lambert law applies for the used concentrations. For all compounds, a pyrene concentration of $5.0 \times 10^{-7} \mathrm{M}$ was used, the slit widths of the excitation and emission monochromators were equaled to 2 and $1 \mathrm{~nm}$, respectively.

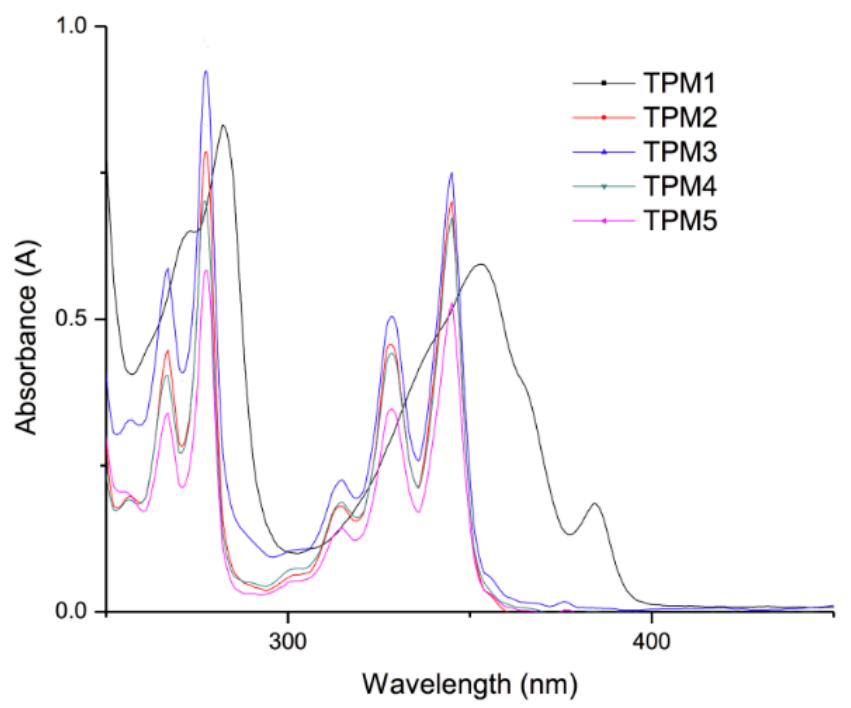

Figure 6. Absorption spectra of the monomers in $\mathrm{CH}_{2} \mathrm{Cl}_{2}$ solution (conc. $1.0 \times 10^{-5} \mathrm{M}$ ). 


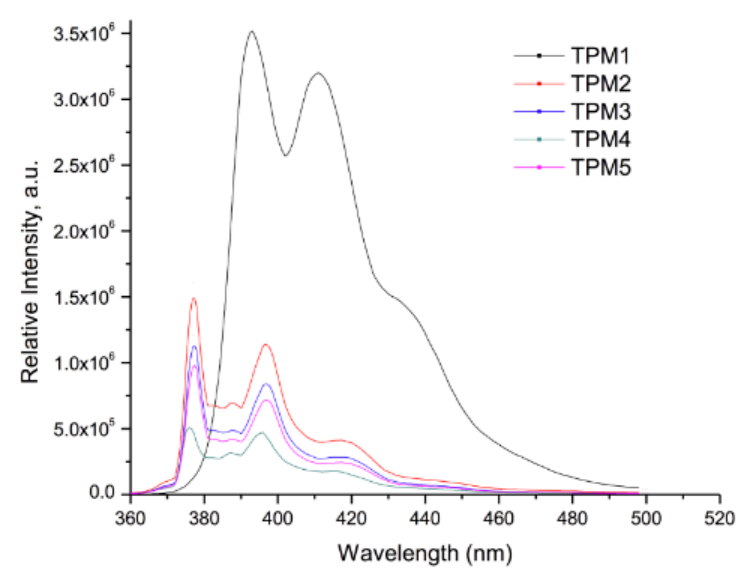

Figure 7. Emission spectra of the monomers in $\mathrm{CH}_{2} \mathrm{Cl}_{2}$ solution (conc. $5 \times 10^{-7} \mathrm{M}$ ).

Table 2. Optical properties of the monomers.

\begin{tabular}{ccccc}
\hline Compound & Absorption $(\boldsymbol{\lambda} \mathbf{~ n m})$ & Cut off $(\mathbf{n m})$ & Emission $(\mathbf{n m})$ & Cut off $(\mathbf{n m})$ \\
\hline TPM1 & 353 & 450 & $391-440^{\mathrm{a}}$ & 500 \\
TPM2 & 345 & 450 & $377-416^{\mathrm{a}}$ & 500 \\
TPM3 & 345 & 450 & $377-416^{\mathrm{a}}$ & 500 \\
TPM4 & 345 & 450 & $377-416^{\mathrm{a}}$ & 500 \\
TPM5 & 345 & 450 & $377-416^{\mathrm{a}}$ & 500 \\
\hline
\end{tabular}

a "Monomer" emission.

The absorption spectra of the monomers in $\mathrm{CH}_{2} \mathrm{Cl}_{2}$ solution (Figure 6) exhibited a well-structured absorption band at $\lambda=345 \mathrm{~nm}$, due to the $S_{0} \rightarrow S_{2}$ transition of the pyrene units. Since the $S_{0} \rightarrow S_{1}$ transition band of this chromophore has a very low intensity and appears at $375 \mathrm{~nm}$, for practical purposes all monomers were excited at $\lambda=345 \mathrm{~nm}$ in order to get good quality emission spectra. As we can observe, monomer TPM1 exhibited a red shifted $S_{0} \rightarrow S_{2}$ absorption band $(\lambda=353$ nm), due to the electron-withdrawing effect of the carbonyl group directly linked to the pyrene unit. In addition, this band shows a significant broadening, which reveals the presence of intramolecular pyrene-thiophene interactions in the ground state. This can be attributed to the short alkyl spacer and the presence of the carbonyl group linked to pyrene. All these monomers exhibited molar extinction coefficient values of $\varepsilon=39,000 \mathrm{M}^{-1} \cdot \mathrm{cm}^{-1}$ at $\lambda=345 \mathrm{~nm}$, very similar to that reported for pyrene itself in THF solution $\left(\varepsilon=45,000 \pm 10,000 \mathrm{M}^{-1} \cdot \mathrm{cm}^{-1}\right)$.

The fluorescence spectra of the monomers are shown in Figure 7. As we can see, all compounds exhibited a broad "monomer" emission band at $377-440 \mathrm{~nm}$, which arises from the $\mathrm{S}_{1} \rightarrow \mathrm{S}_{0}$ transition of pyrene in the non-associated state [32]. It is worth to point out that monomer TPM1 shows a higher intensity emission band compared to those of the other monomers. Besides, this monomer exhibits emission beyond $450 \mathrm{~nm}$, a wavelength where pyrene does not emit (discrete excimer emission). Taking into account these results jointly with those obtained by absorption spectroscopy, we can affirm that we have the presence of intramolecular pyrene-thiophene interactions in this monomer. Except for TPM1, no excimer emission was observed for the other monomers. It is evident that the optical properties of these monomers are mainly dominated by the pyrene unit.

\subsection{Optical Properties of the Polymers}

The optical properties of the oligomers were also studied by absorption and fluorescence spectroscopy in solid state. For that purpose, thin films were prepared with the oligomers by deposition of $\mathrm{CH}_{2} \mathrm{Cl}_{2}$ solutions on ITO/glass plates and the samples were excited at $\lambda_{\text {exc }}=360 \mathrm{~nm}$. The results 
are summarized in Table 3. The UV-vis and emission spectra of the polymers are shown in Figures 8 and 9 respectively.

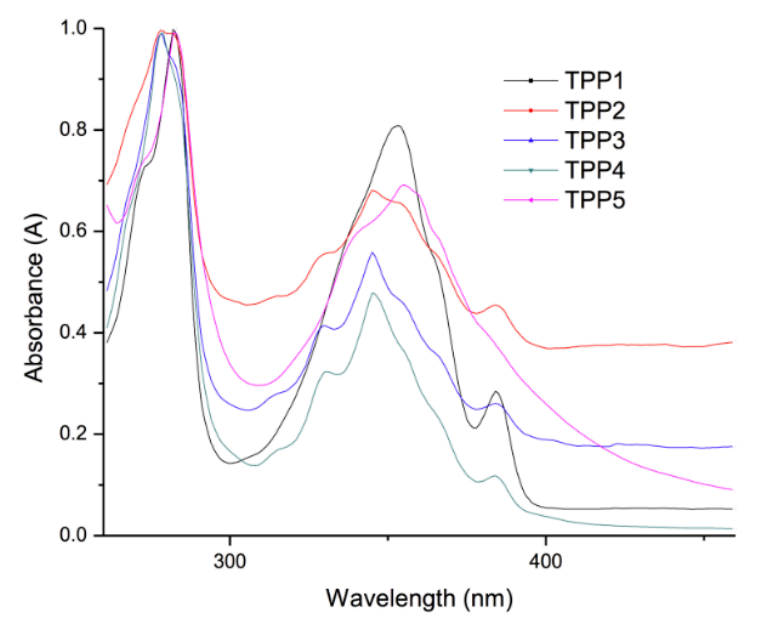

Figure 8. Normalized absorption spectra of the polymers in thin film deposited on ITO/glass.

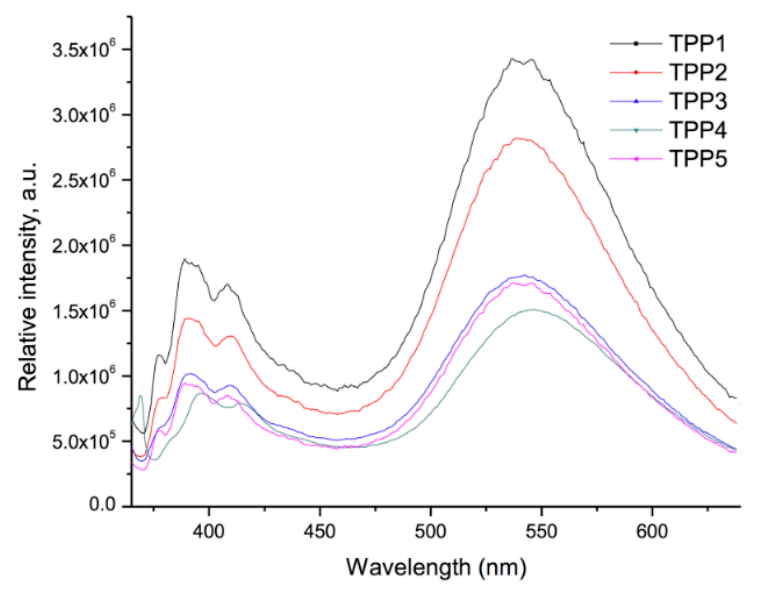

Figure 9. Emission spectra of the polymer films deposited on ITO/glass.

Table 3. Optical properties of the polymers deposited on ITO/glass.

\begin{tabular}{ccccc}
\hline Compound & Absorption $(\lambda \mathbf{n m})$ & Cut off $(\mathbf{n m})$ & Emission $(\lambda \mathbf{n m}) \lambda_{\text {exc }}=\mathbf{3 6 0} \mathbf{n m}$ & Cut off $(\mathbf{n m})$ \\
\hline TPP1 & $275^{\mathrm{b}}-356^{\mathrm{a}}$ & 450 & $388^{\mathrm{c}}, 409^{\mathrm{c}}, 545^{\mathrm{d}}$ & 640 \\
TPP2 & $273^{\mathrm{b}}-345^{\mathrm{a}}$ & 450 & $391^{\mathrm{c}}, 410^{c}, 539^{\mathrm{d}}$ & 640 \\
TPP3 & $273^{\mathrm{b}}-345^{\mathrm{a}}$ & 450 & $389^{\mathrm{c}}, 409^{\mathrm{c}}, 543^{\mathrm{d}}$ & 640 \\
TPP4 & $274^{\mathrm{b}}-345^{\mathrm{a}}$ & 450 & $397^{\mathrm{c}}, 413^{\mathrm{c}}, 543^{\mathrm{d}}$ & 640 \\
TPP5 & $275^{\mathrm{b}}-357^{\mathrm{a}}$ & 450 & $390^{\mathrm{c}}, 409^{\mathrm{c}}, 544^{\mathrm{d}}$ & 640 \\
\hline
\end{tabular}

${ }^{\mathrm{a}}$ : absorption band of the pyrene; ${ }^{\mathrm{b}}:$ absorption band of the polythiophene backbone; ${ }^{\mathrm{c}}:$ monomer emission; ${ }^{\mathrm{d}}$ : excimer emission.

The absorption spectra of polymers TPP1-5 are illustrated in Figure 8. As we can see, all polymers exhibited an absorption band at $c a . \lambda=245 \mathrm{~nm}$ corresponding to $S_{0} \rightarrow S_{1}(n-\pi)$ transition of the polythiophene backbone, which adopts a semi-twisted conformation, followed by a broad band at $\lambda=350 \mathrm{~nm}$ due to the $S_{0} \rightarrow S_{2}$ transition of the pyrene groups. This broadening is a clear indication of the existence of intramolecular pyrene-pyrene interactions in the polymers, which was further confirmed by fluorescence spectroscopy. On the other hand, the emission spectra of the polymers 
(Figure 9) showed a well structured "monomer" emission band at ca. $\lambda=390-410$ nm followed by a very intense broad excimer band at $\lambda=545 \mathrm{~nm}$, which reveals the presence of intramolecular pyrene-pyrene interactions. It is evident that the alkyl spacers jointly with the coiling of the polymer backbone allow pyrene units to encounter even at long distance.

\subsection{Electrochemical Properties of Monomers and Polymers}

During oxidation of the monomers, firstly we can observe the reversible oxidation peak of pyrene as reported in the literature [45]. At higher potential, the thiophene moiety was irreversibly oxidized leading to a classical electropolymerization due to a coupling process of the heterocycles (Figure 10). This was evidenced by square wave voltammetry (SWV), whose main advantage is an excellent sensitivity and the rejection of background currents. For each monomer, we can observe a narrow SWV signal of the reversible oxidation of the pyrene unit, followed by a larger signal due to irreversible oxidation of thiophene. The influence of the molecular structure on the potential oxidation value is illustrated in Figure 10. In monomers TPM2, TPM3 and TPM5, the pyrene moiety is linked to the ester function via an alkyl chain bearing from 3 to 4 carbon atoms. In that case, the pyrene oxidation was recorded at E1/2 $=1.25 \mathrm{~V} / \mathrm{SCE}$ and the thiophene oxidation was measurable from $1.4 \mathrm{~V} / \mathrm{SCE}$. In monomer TPM1, the pyrene moiety was in direct conjugation with the ester function, which resulted in a shift of the oxidation potential value of pyrene to a higher potential about E1/2 $=1.48 \mathrm{~V} / \mathrm{SCE}$. At this potential, the oxidation of thiophene was initiated and developed more largely above $1.6 \mathrm{~V}$. Monomer TPM4 showed an intermediate situation with only one carbon atom between the pyrene ring and the ester function. Here, the pyrene unit was oxidized at $\mathrm{E}_{1 / 2}=1.35 \mathrm{~V} / \mathrm{SCE}$; immediately above this potential, the oxidation of thiophene can be seen.

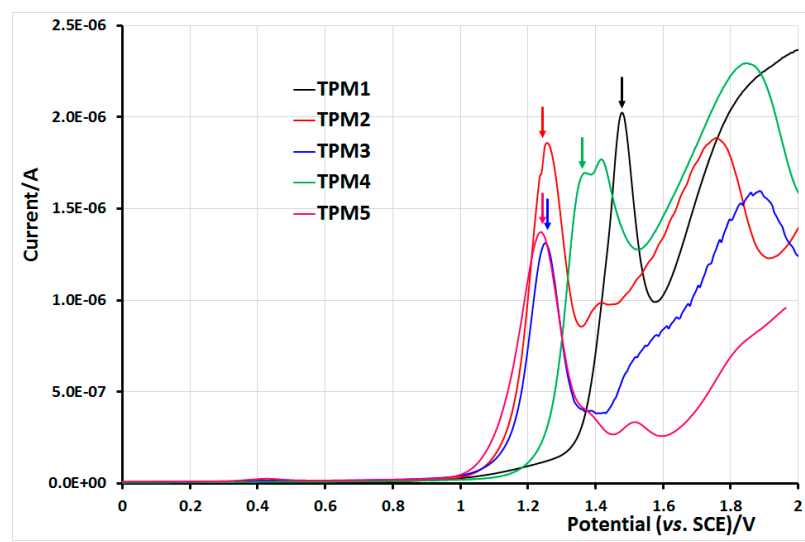

Figure 10. Square wave voltammograms of the monomers in $0.1 \mathrm{M}$ TBA. $\mathrm{PF} 6, \mathrm{CH}_{2} \mathrm{Cl}_{2}$, Pt electrode, vs. $\mathrm{SCE}$, scan speed $100 \mathrm{mV} / \mathrm{s}$. Peaks relative to pyrene oxidation are indicated by thin arrows.

The cyclic voltammogram (CV) under standard conditions (0.1 M TBA. $\mathrm{PF}_{6}, \mathrm{CH}_{2} \mathrm{Cl}_{2}, \mathrm{Pt}, \mathrm{SCE}$, scan speed $200 \mathrm{mV} \cdot \mathrm{s}^{-1}$ ) exhibited several oxidation features. For TPM2, TPM3 and TPM5, on the first scan, we could distinguish the oxidation signal of pyrene followed by that of thiophene. As in the previous case, the oxidation of pyrene occurred at the same potential of $1.25 \mathrm{~V} / \mathrm{SCE}$ (Figure 11 left). When the sweep was pursued until 1.5-1.55 V/SCE, we could see the oxidation signal of thiophene. For TPM2, where the thiophene ring being attached to the ester function through a 2-carbon linker, the ester function had a weak influence on the oxidation potential of the heterocycle ring, which was oxidized just after the pyrene moiety, so that both oxidation signals are fused (see the red curve in Figure 11 left). On the contrary, in monomer TPM5, the thiophene ring was in direct conjugation with the ester function. The withdrawing effect of the ester resulted in a higher oxidation potential of the thiophene ring as demonstrated by the corresponding voltammogram (pink) (Figure 11, left). 

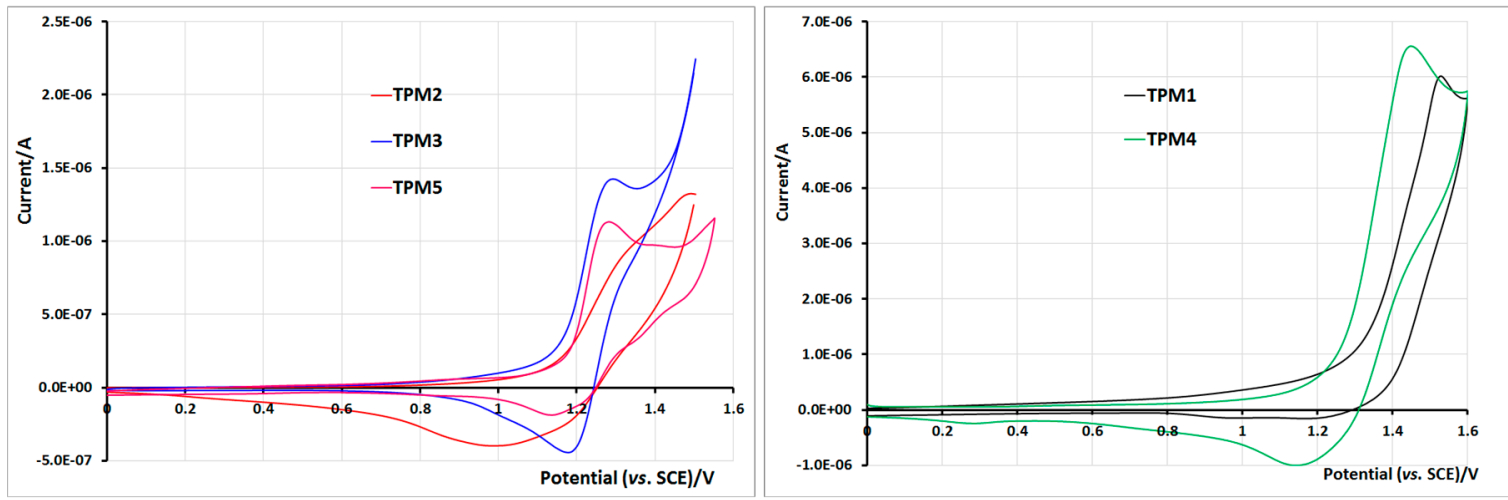

Figure 11. Cyclic voltammetry of monomers TPM2, TPM3 and TPM5 (left) and monomers TPM1 and TPM4 (right) in $0.1 \mathrm{M} \mathrm{TBA} \cdot \mathrm{PF}_{6}, \mathrm{CH}_{2} \mathrm{Cl}_{2}$, Pt electrode, vs. SCE, scan speed $200 \mathrm{mV} / \mathrm{s}$.

The situation of monomer TPM3 is intermediate, with only one carbon atom between the thiophene and the ester function. Its voltammogram exhibited an in-between behavior in comparison to the two preceding cases: the reversible oxidation of pyrene was easily observed and immediately followed by the oxidation of the thiophene ring. For the monomers TPM1 and TPM4, the two oxidation waves of pyrene and thiophene, respectively, were more difficult to distinguish. Since the oxidation potential of pyrene was close to that of thiophene, the corresponding waves overlapped (Figure 11 right).

Homogeneous films of the different polymers were easily synthesized on ITO/glass electrodes in the potentiodynamic mode with $0.1 \mathrm{M} \mathrm{TBA} \cdot \mathrm{PF}_{6}$ dichloromethane solutions of monomers $\left(5 \times 10^{-3} \mathrm{M}\right)$. In each case, the film generated at $100 \mathrm{mV} / \mathrm{s}$ exhibited good electroactivity. To obtain good quality films, the potential range is of significant importance: for example, monomers TPM1 and TPM2 showed similar behaviors during the electropolymerization since in both cases the thiophene ring is linked to the ester function by a 2-carbon chain. While the potential sweep was set between 0 and $1.5 \mathrm{~V} / \mathrm{SCE}$ we could perceive a weak redox signal due to the deposition of a very thin film of low electroactivity (see Figure $12 \mathrm{left}$ ). When the upper limit was fixed at $2 \mathrm{~V} / \mathrm{SCE}$, we observed the development of a perfectly electroactive film in the 0.4-1.5 V/SCE range (Figure 12 right). The growing value of current from cycle to cycle is related to the progressive growing of the electroactive film thickness.
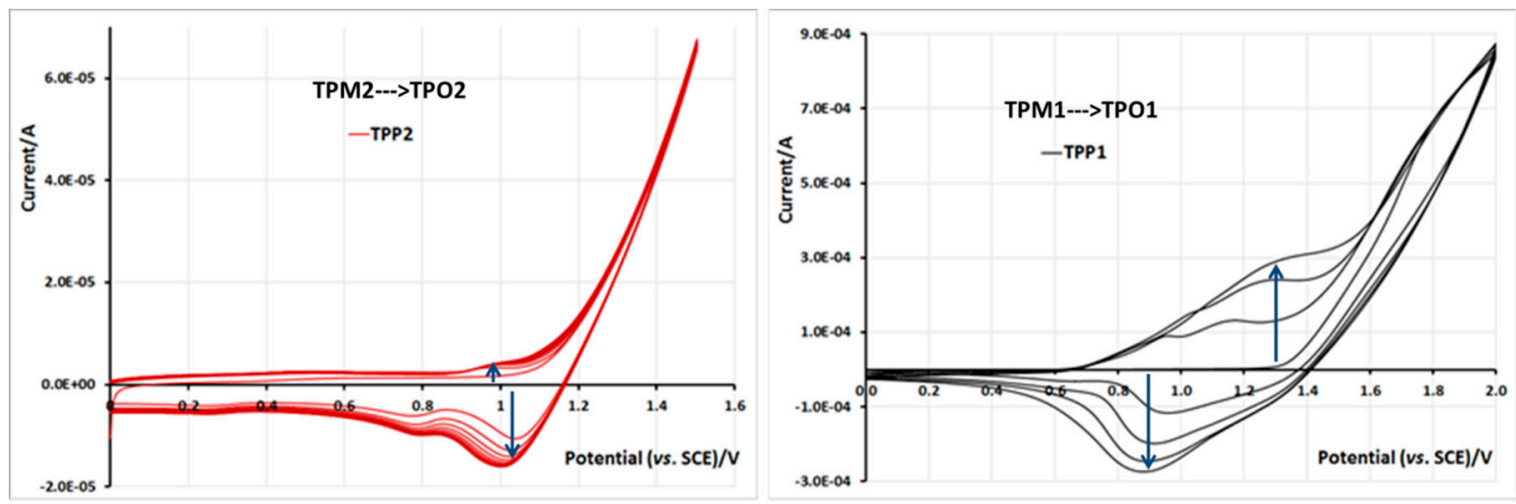

Figure 12. Influence of the potential range on the thickness and electroactivity of the formed film in 0.1 M TBA. $\mathrm{PF}_{6}$ and $5 \times 10^{-3} \mathrm{M}$ of TPM2 (left) and TPM1 (right) in $\mathrm{CH}_{2} \mathrm{Cl}_{2}$, ITO electrode, vs. SCE, scan speed $100 \mathrm{mV} / \mathrm{s}, 6$ and 4 first cycles, respectively.

Monomers TPM3 and TPM4 behaved similarly since their thiophene units are separated from the ester function by only one carbon atom (Figure 13). In both cases, 1.6 V/SCE as the upper potential 
limit is a suitable value to obtain satisfactory growing films. The current values increased regularly from one cycle to another and the films exhibited electroactivity between 0.8 and $1.2 \mathrm{~V} / \mathrm{SCE}$ that means, in a narrower range than for the two preceding polymers.
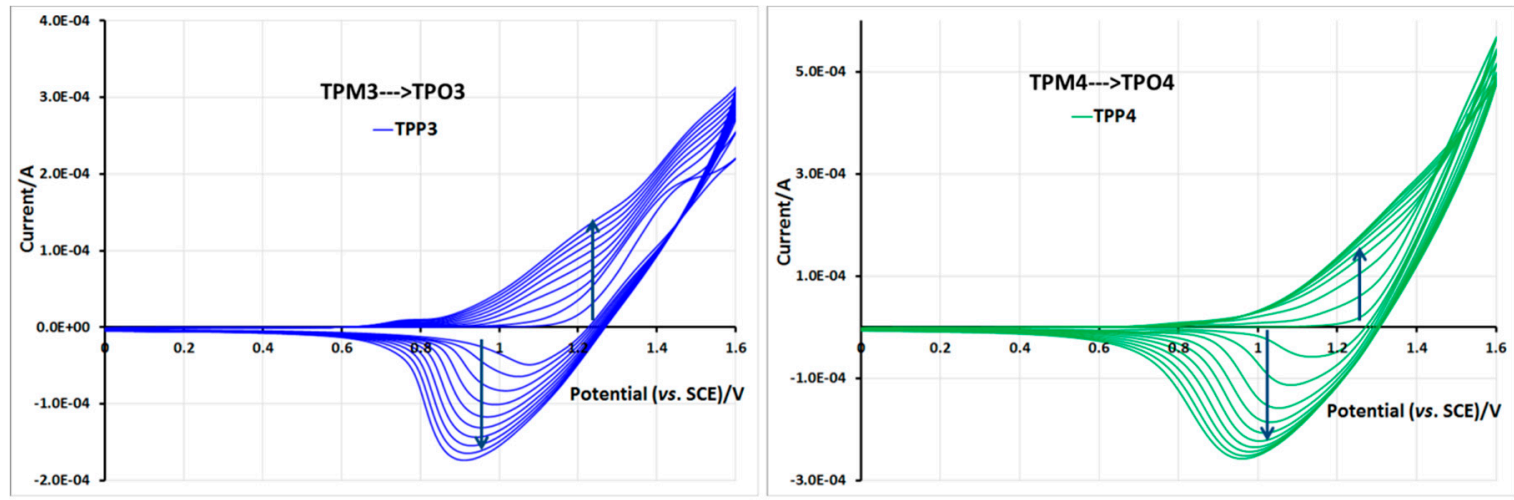

Figure 13. Film formation during cycling in $0.1 \mathrm{M}$ TBA. PF6 and $5 \times 10^{-3} \mathrm{M}$ of TPM3 (left) and TPM4 (right) in $\mathrm{CH}_{2} \mathrm{Cl}_{2}$, and electroactivity of the corresponding polymer films. ITO electrode, potential $v s$. $\mathrm{SCE}$, scan speed $100 \mathrm{mV} / \mathrm{s}$. 10 first cycles.

For monomer TPM5, the potential sweep must be pursued up to $1.8 \mathrm{~V} / \mathrm{SCE}$ to get good quality films; this high potential is necessary because of the electro-withdrawing effect of the ester function directly linked to the thiophene ring. In the voltammogram (Figure 14) recorded during the electropolymerization, we can clearly see the electroactivity of the formed polythiophene in the range of 0.6-1.2 V/SCE, then we can distinguish the redox signal of the pyrene group at ca. 1.0-1.5 V/SCE, and at higher potential the oxidation signal of the thiophene ring. It should be noted that, despite the high oxidation potential value of thiophene, the formed film exhibits a very good electroactivity, thereby showing a good stability towards redox phenomena. These changes can be macroscopically seen by the color change of the polymer films in neutral state, which have a color between transparent and light yellow, whereas the oxidized polymer films adopt a color between yellow and orange.

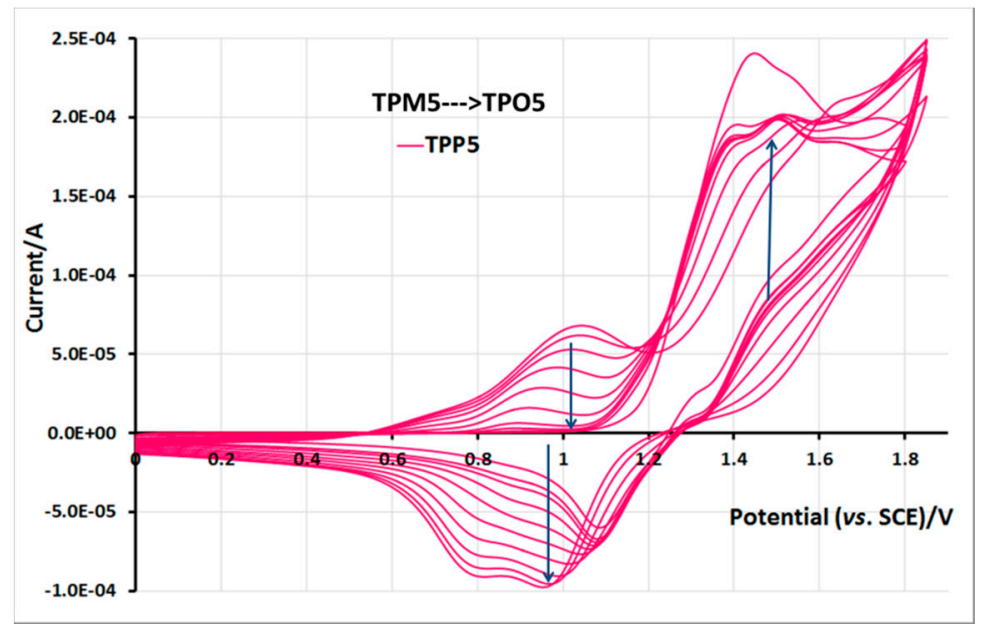

Figure 14. Film formation during cycling in $0.1 \mathrm{M} \mathrm{TBA} \cdot \mathrm{PF}_{6}$ and $5 \times 10^{-3} \mathrm{M}$ of TPM5 in $\mathrm{CH}_{2} \mathrm{Cl}_{2}$, and electroactivity of the corresponding polymer film. ITO electrode, potential vs. SCE, scan speed $100 \mathrm{mV} / \mathrm{s} .10$ first cycles.

The most important point here is that, for all monomers, even if pyrene was submitted to redox process during the formation of the film, this chromophore did not interfere in the 
electropolymerization process. This feature allowed us to synthesize polythiophene films bearing pyrene units on surface by electrochemical means. Since the electroactivity potential range of the polythiophene ring is very different of that of pyrene, the polymers can be held in their oxidized or neutral state without affecting the redox state of pyrene.

To clarify this point we made a comparison between the voltammograms of the TPM polymers and non-substituted pyrene [46]. This chromophore shows two oxidation anodic peaks at 1.338 (middle intensity) and $1.572 \mathrm{~V}$ (intense) with higher potential values than those found for our synthesized monomers TPM2-4 (1.25 V), where the pyrene unit is not directly linked to the ester. By contrast, in TPM1 the pyrene oxidation potential was shifted to 1.48 because it is directly attached to the ester. The cyclic voltammetry of non-substituted pyrene shows also two discrete anodic reduction peaks at 0.616 and $0.790 \mathrm{~V}$, whereas TPM monomers exhibit more intense catodic reduction peaks between 0.8 and $1.2 \mathrm{~V}$. By comparing the cyclic voltammograms of the TPM monomers with that of pyrene itself, we confirm that the thiophene moiety exhibits higher electroactivity towards polymerization.

\section{Experimental Section}

\subsection{Apparatus}

FTIR spectra of the monomers and polymers were recorded on a $510 \mathrm{P}$ spectrometer (Nicolet, Madison, WI., USA) in solid state. ${ }^{1} \mathrm{H}$ - and ${ }^{13} \mathrm{C}-\mathrm{NMR}$ spectra of all compounds were carried out in $\mathrm{CDCl}_{3}$ solution, in a Bruker Avance 300 spectrometer (Bruker, Coventry, UK), operating at $300 \mathrm{MHz}$ and $75 \mathrm{MHz}$ for ${ }^{1} \mathrm{H}$ and ${ }^{13} \mathrm{C}$, respectively. Molecular weights of the monomers were determined by mass spectrometry using a chemical ionization technique in a Bruker-Microflex spectrometer (Bruker, Coventry, UK).

For the oligomers, the molecular weights were determined by MALDI-TOF ${ }^{+}$in positive mode, using trans-2-[3-(4-t-butyl-phenyl)-2-methyl-1,2-propenylidene]malonitrile (DCTB) as matrix in a Bruker-Microflex mass spectrometer. The mass spectrometry analysis showed the molecular ion peaks $\left[\mathrm{M}^{+}\right]$with the corresponding $\mathrm{m} / \mathrm{z}$ values for each molecule.

The thermal stability of the compounds was determined by thermogravimetric analysis (TGA) and conducted on a Hi-Res TGA 2950 Instrument (TA Instruments, New Castle, DE, USA). The melting point of monomers and oligomers as well as the glass transition temperature $(\mathrm{Tg})$ were measured with a Differential Scanning Calorimeter (MDSC) TA Instruments 2920 (TA Instruments).

Absorption spectra of the monomers in $\mathrm{CH}_{2} \mathrm{Cl}_{2}$ solution (spectrometric grade, concentration $1 \times 10^{-5} \mathrm{M}$ ) were recorded on a Varian Cary 1 Bio UV-vis spectrophotometer (Agilent Technologies, Les Ulis, France) model 8452A. Fluorescence spectra corrected for emission detection were recorded on a LS-100 steady-state instrument (Photon Technology International, London, ON, Canada) equipped with a continuous UXL-75Xe Xenon arc lamp (Ushio, Cypress, CA, USA) and a PTI 814 photomultiplier detection system. The slit widths on the excitation and emission monochromators were equaled to 2 and $1 \mathrm{~nm}$, respectively, for the monomers, and 4 and 9 for the polymers. Each solution was excited at $\lambda=345 \mathrm{~nm}$ using a $1 \mathrm{~cm}$ quartz cell. For all monomers, a concentration of $5 \times 10^{-7} \mathrm{M}$ was employed in order to obtain an absorbance value of 0.05 at $\lambda=345 \mathrm{~nm}$, to avoid any inner filter effect [47].

Cyclic voltammetry measurements were performed with an Autolab PGSTAT100 potentiostat controlled by GPES 4.09 software (HORIBA Jobin Yvon SAS, Longjumeau, France). All experiments were carried out at room temperature $(298 \pm 2 \mathrm{~K})$, in a homemade airtight three-electrode cell connected to a vacuum/argon line. Cyclic voltammograms were recorded at a scan rate of $100 \mathrm{mV} / \mathrm{s}$ on Pt and the obtained polymers were deposited on ITO on glass plates $(0.8 \mathrm{~cm} \times 5.0 \mathrm{~cm})$ at $200 \mathrm{mV} / \mathrm{s}$. ITO/glass plates were purchased from SOLEMS and consisted of $100 \mathrm{~nm}$ thickness ITO (25-35 ohms) deposited on glass (1.1 mm thick). 


\subsection{Chemicals}

$N, N^{\prime}$-Dicyclohexylcarbodiimide (DCC, 99\%) and 4-dimethylaminopyidine (DMAP) (99\%), 1-pyrenemethanol, 3-thiopheneacetic acid 98\%, 3-thiopheneethanol, 1-pyrenebutyric acid, 1-pyrenecarboxylic acid 98\%, thiophene carboxylic acid, and $\mathrm{FeCl}_{3}$ were purchased from Sigma Aldrich (Mexico City, Mexico) and used as received. Dichloromethane $\left(\mathrm{CH}_{2} \mathrm{Cl}_{2}\right), \mathrm{n}$-hexane and chloroform $\left(\mathrm{CHCl}_{3}\right)$ were purchased from Tecsiquim (Mexico City, Mexico). Chloroform, used in the polymerizations was distilled over calcium hydride $\left(\mathrm{CaH}_{2}\right)$ in order to remove traces of water.

\subsection{Electrochemical Polymerization}

A saturated calomel electrode (SCE) separated from the solution by a bridge compartment was used as the reference electrode. The counter electrode was a platinum wire of $c a .1 \mathrm{~cm}^{2}$ apparent surface. For electrochemical examination of the monomers, the working electrode was a platinum microdisk (radius $=0.25 \mathrm{~mm}$ ). The platinum electrode was polished prior to use in a rotatory plate. Then it was rinsed with acetone and dried with a tissue. For the electropolymerization, the working electrode was an ITO coated glass (active surface $=1 \mathrm{~cm}^{2}$ ). The ITO/glass electrode was sonicated in acetonitrile, then rinsed with ethanol, and allowed to dry at room temperature in a dust-free atmosphere before using it. The monomer solution concentration used during electrochemical studies was typically $5 \times 10^{-3} \mathrm{M}$. The electrolyte solution consisted of $0.10 \mathrm{M} \mathrm{Bu}_{4} \mathrm{NPF}_{6}$ (electrochemical grade from Fluka) in anhydrous $\mathrm{CH}_{2} \mathrm{Cl}_{2}$ (Aldrich $99.8 \%,<0.001 \% \mathrm{H}_{2} \mathrm{O}$ ). $\mathrm{CH}_{2} \mathrm{Cl}_{2}$ (HPLC grade) was used as received and transferred via a syringe under nitrogen. All the solutions were degassed with high purity argon, which was pre-saturated with the solvent before entering the cell. The useful potential range for the electrolytic medium was from $2 \mathrm{~V}$ to $-2.5 \mathrm{~V}$. Ferrocene $(\mathrm{Fc})$ was employed as an internal reference to ensure the accuracy of the calomel reference electrode. The $\mathrm{Fc}+/ \mathrm{Fc}$ couple in $\mathrm{CH}_{2} \mathrm{Cl}_{2}$ was regularly checked, and a constant value of $0.45 \mathrm{~V} / \mathrm{SCE}$ was measured. All potentials were referenced relative to the saturated calomel electrode.

\subsection{Synthesis of the Monomers}

General Synthesis

The appropriate thiophene alcohol $(0.82 \mathrm{mmol})$, the selected carboxylic acid $(1.23 \mathrm{mmol}), \mathrm{DCC}$ (2.46 mmol) and DMAP $(2.05 \mathrm{mmol})$ were dissolved in $\mathrm{CH}_{2} \mathrm{Cl}_{2}(15 \mathrm{~mL})$ at $0{ }^{\circ} \mathrm{C}$ for $30 \mathrm{~min}$. The resulting mixture was stirred at room temperature for $12 \mathrm{~h}$ under inert atmosphere. The suspension was filtered in order to remove DCU formed during the reaction, and the filtrates were concentrated under reduced pressure at $45^{\circ} \mathrm{C}$. The crude product was purified by column chromatography in silica gel, using $n$-hexane $/ \mathrm{CH}_{2} \mathrm{Cl}_{2}$ (2:5) and then pure $\mathrm{CH}_{2} \mathrm{Cl}_{2}$ as eluent to give the desired product TPM1 (Figure 1). All monomers were characterized by ${ }^{1} \mathrm{H}$ - and ${ }^{13} \mathrm{C}-\mathrm{NMR}$ spectroscopy and the spectra are included in the Supplementary Materials.

2-(Thiophen-3-yl)ethylpyrene-1-carboxylate (TPM1): 3-Thiopheneethanol (0.105 g, $0.82 \mathrm{mmol})$, 1-pyrenecarboxylic acid $(0.302 \mathrm{~g}, 1.23 \mathrm{mmol}), \mathrm{DCC}(0.507 \mathrm{~g}, 2.46 \mathrm{mmol})$ and DMAP $(0.250 \mathrm{mg}$, $2.05 \mathrm{mmol})$. Light yellow powder. Yield: $87 \%$. MS-CI: $m / z=356.0 .{ }^{1} \mathrm{H}-\mathrm{NMR}\left(\mathrm{CDCl}_{3}, \mathrm{ppm}\right)$ (Scheme

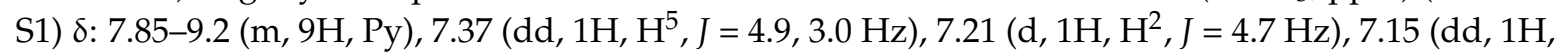
$\left.\mathrm{H}^{4}, J=4.9,1.3 \mathrm{~Hz}\right), 4.76(\mathrm{t}, 2 \mathrm{H}, J=6.8 \mathrm{~Hz}), 3.26(\mathrm{t}, 2 \mathrm{H}, J=6.8 \mathrm{~Hz}) .{ }^{13} \mathrm{C}-\mathrm{NMR}\left(\mathrm{CDCl}_{3}, \mathrm{ppm}\right)$ (Scheme S1-1): 168.09 (C=O), 155.31 ( $C^{2}$, Thioph), 138.38 ( $C^{3}$, Thioph), $117.89\left(C^{4}\right.$, Thioph), $96.24\left(C^{1}\right.$, Thioph), $134.41,131.19,131.09,130.46,129.72,129.51,128.47,127.25,126.40,126.38,126.27,125.91,124.98,124.24$, 123.71, $121.94\left(\mathrm{C}_{\mathrm{Py}}\right), 65.23\left(\mathrm{OCH}_{2}\right), 29.94\left(\mathrm{CH}_{2}\right)$.

2-(Thiophen-3-yl)ethyl 4-(pyren-1-yl)butanoate (TPM2): 3-Thiopheneethanol (0.105 g, $0.82 \mathrm{mmol})$, 1-pyrenebutyric acid $(0.355 \mathrm{~g}, 1.23 \mathrm{mmol})$, DCC $(0.507 \mathrm{~g}, 2.46 \mathrm{mmol})$ and DMAP $(0.250 \mathrm{mg}, 2.05 \mathrm{mmol})$. White powder. Yield: $82 \%$. MS-CI: $m / z=398.1 .{ }^{1} \mathrm{H}-\mathrm{NMR}\left(\mathrm{CDCl}_{3}, 300 \mathrm{MHz}, \mathrm{ppm}\right)$ (Scheme S2) $\delta$ (ppm): 7.82-8.32 (m, 9H, Py), $7.23\left(\mathrm{dd}, 1 \mathrm{H}, \mathrm{H}^{5}, J=4.7,3.1 \mathrm{~Hz}\right), 7.01\left(\mathrm{~d}, 1 \mathrm{H}, \mathrm{H}^{2}, J=4.6 \mathrm{~Hz}\right), 6.95(\mathrm{dd}, 1 \mathrm{H}$, 
$\left.\mathrm{H}^{4}, J=4.9,1.1 \mathrm{~Hz}\right), 4.31\left(\mathrm{t}, 2 \mathrm{H}, \mathrm{H}^{\beta}, J=7.0 \mathrm{~Hz}\right), 3.37\left(\mathrm{t}, 2 \mathrm{H}, \mathrm{H}^{\alpha}, J=6.6 \mathrm{~Hz}\right), 2.96\left(\mathrm{t}, 2 \mathrm{H}, \mathrm{H}^{6}, J=6.9 \mathrm{~Hz}\right)$, $2.49\left(\mathrm{t}, 2 \mathrm{H}, \mathrm{H}^{8}, J=7.2 \mathrm{~Hz}\right), 2.09-2.30\left(\mathrm{~m}, 2 \mathrm{H}, \mathrm{H}^{7}\right) .{ }^{13} \mathrm{C}-\mathrm{NMR}\left(\mathrm{CDCl}_{3}, 75 \mathrm{MHz}, \mathrm{ppm}\right)$ (Scheme S2-1): $174.17\left(\mathrm{C}=\mathrm{O}, \mathrm{C}_{\mathrm{a}}\right), 155.30$ ( $\mathrm{C}^{2}$, Thioph), $138.28\left(\mathrm{C}^{3}\right.$, Thioph), $124.57\left(\mathrm{C}^{4}\right.$, Thioph), $116.61\left(\mathrm{C}^{1}\right.$, Thioph), 137.38, 136.38, 130.04, 126.81, 126.47, 126.16, 125.81, 125.57, 125.54, 124.98, 124.57, 124.24, 122.71, 121.74 $\left(\mathrm{C}_{\mathrm{Py}}\right), 63.02\left(\mathrm{OCH}_{2}, \mathrm{C}_{\mathrm{b}}\right), 36.17,34.38,30.45,23.47\left(\mathrm{CH}_{2}, \mathrm{C}_{\mathrm{c}}\right), 33.36\left(\mathrm{Py}_{-} \mathrm{CH}_{2}\right)$.

4-(Pyren-1-yl)butyl 2-(thiophen-3-yl)acetate (TPM3): 3-Thiopheneacetic acid $(0.110 \mathrm{~g}, 0.78 \mathrm{mmol})$, 1-pyrenebutanol (0.224 g, $0.82 \mathrm{mmol})$, DCC ( $0.507 \mathrm{~g}, 2.46 \mathrm{mmol})$ and DMAP $(0.250 \mathrm{mg}, 2.05 \mathrm{mmol})$. Light yellow powder. Yield: $76 \%$, MS-CI: $m / z=398.1 .{ }^{1} \mathrm{H}-\mathrm{NMR}\left(\mathrm{CDCl}_{3}, 300 \mathrm{MHz}, \mathrm{ppm}\right)$ (Scheme S3) $\delta$ (ppm): $7.85-8.3(\mathrm{~m}, 9 \mathrm{H}, \mathrm{Py}), 7.24\left(\mathrm{dd}, 1 \mathrm{H}, \mathrm{H}^{5}, J=4.9,3.1 \mathrm{~Hz}\right), 7.12\left(\mathrm{~d}, 1 \mathrm{H}, \mathrm{H}^{2}, J=4.7 \mathrm{~Hz}\right), 7.00(\mathrm{~d}$, $\left.1 \mathrm{H}, \mathrm{H}^{4}, J=4.9,1.3 \mathrm{~Hz}\right), 4.15(\mathrm{dt}, 2 \mathrm{H}, J=14.3,6.8 \mathrm{~Hz}), 3.64\left(\mathrm{~s}, 2 \mathrm{H}, \mathrm{H}^{\alpha}\right), 3.36\left(\mathrm{t}, 2 \mathrm{H}, \mathrm{H}^{6}, J=7.5 \mathrm{~Hz}\right), 1.87$ $\left(\mathrm{m}, 2 \mathrm{H}, \mathrm{H}^{8}\right), 1.27\left(\mathrm{t}, 2 \mathrm{H}, \mathrm{H}^{9}, J=7.1 \mathrm{~Hz}\right) .{ }^{13} \mathrm{C}-\mathrm{NMR}\left(\mathrm{CDCl}_{3}, 75 \mathrm{MHz}, \mathrm{ppm}\right)$ (Scheme S3-1): $171.28(\mathrm{C}=\mathrm{O}$, $\left.C_{a}\right), 156.21$ ( $C^{2}$, Thioph), 136.38 ( $C^{3}$, Thioph), 133.77 ( $C^{4}$, Thioph), 115.52 ( $C^{1}$, Thioph), 131.55, 131.00, $129.99,128.71,128.57,127.61,127.41,127.33,126.76,125.95,125.79,125.14,125.02,124.91,124.84,123.37$ $\left(\mathrm{C}_{\mathrm{Py}}\right), 64.85\left(\mathrm{OCH}_{2}, \mathrm{C}_{\mathrm{b}}\right), 36.04,33.09,28.69,28.15\left(\mathrm{CH}_{2}\right)$.

Pyren-1-ylmethyl 2-(thiophen-3-yl)acetate (TPM4): 3-Thiopheneacetic acid $(0.110 \mathrm{~g}, 0.78 \mathrm{mmol})$, 1-pyrenemethanol (0.190 g, $0.82 \mathrm{mmol})$, DCC (0.507 g, $2.46 \mathrm{mmol})$ and DMAP $(0.250 \mathrm{mg}, 2.05 \mathrm{mmol})$. Beige powder. Yield: $65 \%$, MS-CI: $m / z=356 .{ }^{1} \mathrm{H}-\mathrm{NMR}\left(\mathrm{CDCl}_{3}, 300 \mathrm{MHz}, \mathrm{ppm}\right)$ (Scheme S4): $\delta$ (ppm): 8.02-8.24 (m, 9H, Py), $7.23\left(\mathrm{dd}, 1 \mathrm{H}, \mathrm{H}^{5}, J=4.6,3.1 \mathrm{~Hz}\right), 7.15\left(\mathrm{~d}, 1 \mathrm{H}, \mathrm{H}^{2}, J=3.2 \mathrm{~Hz}\right), 7.04\left(\mathrm{dd}, 1 \mathrm{H}, \mathrm{H}^{4}\right.$, $J=4.9,1.3 \mathrm{~Hz}), 5.85\left(\mathrm{~s}, 2 \mathrm{H}, \mathrm{H}^{6}\right), 3.73\left(\mathrm{~s}, 2 \mathrm{H}, \mathrm{H}^{\alpha}\right) .{ }^{13} \mathrm{C}-\mathrm{NMR}\left(\mathrm{CDCl}_{3}, 75 \mathrm{MHz}, \mathrm{ppm}\right)$ (Scheme S4-1): $168.51\left(\mathrm{C}=\mathrm{O}, \mathrm{C}_{\mathrm{a}}\right), 151.41\left(\mathrm{C}^{2}\right.$, Thioph), $138.44\left(\mathrm{C}^{3}\right.$, Thioph), 136.26 ( $\mathrm{C}^{4}$, Thioph), $120.74\left(\mathrm{C}^{1}\right.$, Thioph), 132.94, 132.26, 131.60, 130.04, 129.59, 129.17, 127.72, 126.90, 126.81, 126.10, 124.90, 123.81, 122.52, 12.41, $121.75\left(\mathrm{C}_{\mathrm{Py}}\right), 64.70\left(\mathrm{OCH}_{2}, \mathrm{C}_{\mathrm{b}}\right), 36.17\left(\mathrm{CH}_{2}, \mathrm{C}_{\mathrm{c}}\right), 32.00\left(\mathrm{Py}_{-}-\mathrm{CH}_{2}, \mathrm{C}_{\mathrm{d}}\right)$.

4-(Pyren-1-yl)butyl thiophene-3-carboxylate (TPM5): 1-Pyrenecarboxylic acid (0.157 g, $1.22 \mathrm{mmol})$, 1-pyrenebuthanol (0.224 g, $0.82 \mathrm{mmol})$, DCC (0.507 g, $2.46 \mathrm{mmol})$ and DMAP (0.250 mg, $2.05 \mathrm{mmol})$. White powder. Yield: $79 \%$, MS-CI: $m / z=384.1 .{ }^{1} \mathrm{H}-\mathrm{NMR}\left(\mathrm{CDCl}_{3}, 300 \mathrm{MHz}, \mathrm{ppm}\right)$ (Scheme S5) $\delta$ (ppm): $7.80-8.23(\mathrm{~m}, 9 \mathrm{H}, \mathrm{Py}), 7.51\left(\mathrm{dd}, 1 \mathrm{H}, \mathrm{H}^{5}, J=5.1,1.2 \mathrm{~Hz}\right), 7.28\left(\mathrm{~d}, 1 \mathrm{H}, \mathrm{H}^{2}, J=3.1 \mathrm{~Hz}\right), 7.02\left(\mathrm{~d}, 1 \mathrm{H}, \mathrm{H}^{4}\right.$, $J=4.9 \mathrm{~Hz}), 4.36\left(\mathrm{t}, 2 \mathrm{H}, \mathrm{H}^{6}, J=6.4 \mathrm{~Hz}\right), 3.41\left(\mathrm{t}, 2 \mathrm{H}, \mathrm{H}^{9} J=7.1 \mathrm{~Hz}\right), 1.75-2.17\left(\mathrm{~m}, 4 \mathrm{H}, \mathrm{H}^{7}, \mathrm{H}^{8}\right) .{ }^{13} \mathrm{C}-\mathrm{NMR}$ $\left(\mathrm{CDCl}_{3}, 75 \mathrm{MHz}, \mathrm{ppm}\right)$ (Scheme S5-1): $162.94\left(\mathrm{C}=\mathrm{O}, \mathrm{C}_{\mathrm{a}}\right), 151.51\left(\mathrm{C}^{2}\right.$, Thioph), $136.40\left(\mathrm{C}^{3}\right.$, Thioph), 133.94 ( $C^{4}$, Thioph), 100.01 ( $C^{1}$, Thioph), 131.55, 131.00, 129.99, 128.71, 128.00, 127.61, 127.59, 127.40, $127.35,125.93,125.22,125.01,124.91,124.83,123.83\left(\mathrm{C}_{\mathrm{Py}}\right), 64.57\left(\mathrm{OCH}_{2}, \mathrm{C}_{\mathrm{b}}\right), 33.14,28.79,28.21\left(\mathrm{CH}_{2}\right)$.

\subsection{Synthesis of the Oligomers and the Polymers}

For the obtainment of the pyrene containing polythiophenes, chemical and electrochemical polymerization methods were employed. When a chemical polymerization was carried out only oligomers were obtained; this was confirmed by MALDI-TOF spectrometry (Schemes S11-S15).

\subsubsection{Chemical Polymerization}

All the oligomers (Figure 2) were obtained according to the procedure previously reported in the literature [18]. The appropriate TPM monomer $(0.216 \mathrm{mmol})$ was dissolved in dry $\mathrm{CHCl}_{3}(20 \mathrm{~mL})$ and the solution was stirred for 10 min under inert atmosphere. Afterwards, a solution of $\mathrm{FeCl}_{3}$ $(0.864 \mathrm{mmol})$ in $\mathrm{CHCl}_{3}(10 \mathrm{~mL})$ was prepared and added dropwise to the monomer solution; then it was stirred for $12 \mathrm{~h}$. After this time, cold methanol $(20 \mathrm{~mL})$ was added to the reaction mixture, which was poured into ice-water $(60 \mathrm{~mL})$ in order to precipitate the polymer. The crude product was separated by filtration, washed with cold methanol and treated with $\mathrm{NH}_{4} \mathrm{OH} 20 \%$ in order to reduce the crude product, because the polymer was obtained in the oxidized form. Finally, the polymer was purified by Soxhlet extraction, using a mixture of methanol:water 8:2. After $12 \mathrm{~h}$, the mixture of solvents was changed by pure acetone, and the compound was extracted for 12 more hours. The final 
wash was carried out with cold pure methanol $\left(0-5^{\circ} \mathrm{C}\right)$ and the compound was filtered in a Buchner under vacuum to give the desired TPO oligomer (Figure 2).

\subsubsection{Synthesis of TPO1-5}

TPM1 (0.077 g, $0.216 \mathrm{mmol}) \mathrm{FeCl}_{3}(0.14 \mathrm{~g}, 0.864 \mathrm{mmol})$. Oligomer TPO1 (Figure 2): orange powder. Yield: 71\%. MALDI-TOF ${ }^{+}$; homopolymers, $m / z=1064.5(n=3), 1418.2(n=4), 1772.1(n=5), 2126.4$ $(n=6)$ (Scheme S11).

TPM2 (0.216 mmol) $\mathrm{FeCl}_{3}(0.14 \mathrm{~g}, 0.864 \mathrm{mmol})$. TPO2 (Figure 2): light orange powder. Yield: 68\%. MALDI-TOF ${ }^{+}$; homopolymers: $m / z=1190.4(n=3), 1586.6(n=4), 1982.9(n=5), 2379.1(n=6), 2774.3$ $(n=7), 3171.4(n=8)$ (Scheme S12).

TPM3 (0.086 g, $0.216 \mathrm{mmol}), \mathrm{FeCl}_{3}(0.14 \mathrm{~g}, 0.864 \mathrm{mmol})$. TPO3 (Figure 2): brown powder. Yield: $74 \%$. MALDI-TOF ${ }^{+}$; homopolymers, $m / z=1190.5(n=3), 1586.7(n=4), 1983.0(n=5), 2379.3(n=6)$ (Scheme S13).

TPM4 (0.077 g, $0.216 \mathrm{mmol}), \mathrm{FeCl}_{3}(0.14 \mathrm{~g}, 0.864 \mathrm{mmol})$. TPO4 (Figure 2): brown solid. Yield: 46\%. MALDI-TOF $^{+}$; homopolymers, $m / z=1185.7(n=3), 1418.7(n=4), 1772.6(n=5)$ (Scheme S14).

TPM5 (0.083 g, $0.216 \mathrm{mmol}), \mathrm{FeCl}_{3}(0.14 \mathrm{~g}, 0.864 \mathrm{mmol})$. TPO5 (Figure 2): dark brown powder. Yield: 69\%. MALDI-TOF ${ }^{+}$; homopolymers, $m / z=766.3(n=2), 1148.4(n=3), 1530.5(n=4), 1912.5(n=5)$, $2294.2(n=6), 2676.4(n=7), 3058.3(n=8)$ (Scheme S15).

\subsection{Thermal Analysis}

The thermogravimetric analysis (TGA) was determinate and conducted with samples of $5 \mathrm{mg}$ on a with a heating rate of $10^{\circ} \mathrm{C} / \mathrm{min}$. The melting point and the glass transition temperature $\left(\mathrm{T}_{\mathrm{g}}\right)$ were measured with samples of $5-10 \mathrm{mg}$, from -50 to $250{ }^{\circ} \mathrm{C}$, with a heating rate of $5{ }^{\circ} \mathrm{C} / \mathrm{min}$, under $\mathrm{N}_{2}$ flux of $50 \mathrm{cc} / \mathrm{min}$, with a period of $40 \mathrm{~s}$ and an amplitude of $0.5^{\circ} \mathrm{C}$. (Schemes S6-S10).

\section{Conclusions}

A new series of monomers, oligo and polythiophenes bearing pyrene units and flexible alkyl spacers were synthesized and characterized. These novel compounds exhibited a good thermal stability with $\mathrm{T}_{10}$ values between 256 and $299^{\circ} \mathrm{C}$ and $\mathrm{Tg}$ values varying from 36 to $39^{\circ} \mathrm{C}$. Except for monomer TPM1, which exhibited an absorption band at $353 \mathrm{~nm}$, the other monomers and polymers exhibited absorption bands at $\lambda=345 \mathrm{~nm}$ due to $S_{0} \rightarrow S_{2}$ transition of the pyrene groups. The fluorescence spectra of the obtained polymers showed two emission bands, a "monomer" emission at $\lambda=390-410 \mathrm{~nm}$, followed by an intense excimer emission at $\lambda=539-545 \mathrm{~nm}$, which reveals the presence of intramolecular pyrene-pyrene interactions. We found that all the monomer may be electropolymerized to generate electroactive thin films deposited onto ITO. These films were constituted of polythiophene chains with pending pyrene units, which did not participate in the electropolymerization process. These materials can be held in their oxidized or neutral state and the polymerization occurs exclusively in the thiophene rings. Moreover, the pyrene units can act as a fluorescent probe or anchor to other conjugated materials such as graphene by $\pi-\pi$ interactions, which make these materials very promising for a wide variety of applications in the field of organic electronics.

Supplementary Materials: Supplementary materials can be accessed at: http://www.mdpi.com/1420-3049/ $21 / 2 / 172 / s 1$.

Acknowledgments: We thank Alix Saquet and Marine Tasse (LCC-CNRS, Toulouse), Miguel A. Canseco, Gerardo Cedillo and Damaris Cabrero (IIM-UNAM) for their technical assistance in the characterization of the polymers. BXVG is grateful to UNAM and CONACYT for academic and scholarship (Grant 227091). We also thank PAPIIT-DGAPA (Project IN-100513) for financial support. This work has been also performed within the Framework of the French-Mexican International Laboratory (LIA-LCMMC) supported by CNRS and CONACyT. 
Author Contributions: Bianca X. Valderrama-García (Monomer, oligomer and polymer synthesis); Efraín Rodríguez-Alba (Spectroscopical characterization) Eric G. Morales-Espinoza (Thermal analysis), Kathleen Moineau Chance-Ching (Electrochemistry) and Ernesto Rivera (Absorption and fluorescence spectroscopy).

Conflicts of Interest: The authors declare no conflict of interest.

\section{References}

1. Javadi, A.; Najjar, W.; Bahadori, S.; Vatanpour, V.; Malek, A.; Abouzari-Lotf, E.; Shockravi, A. High refractive index and low-birefringence polyamides containing thiazole and naphthalene units. RSC Adv. 2015, 5, 91670-91682. [CrossRef]

2. Fukuzaki, N.; Higashihara, T.; Ando, S.; Ueda, M. Synthesis and Characterization of Highly Refractive Polyimides Derived from Thiophene-Containing Aromatic Diamines and Aromatic Dianhydrides. Macromolecules 2010, 43, 1836-1843. [CrossRef]

3. Javadi, A.; Shockravi, A.; Rafieimanesh, A.; Malek, A.; Ando, S. Synthesis and structure-property relationships of novel thiazole-containing poly(amide imide)s with high refractive indices and low birefringences. Polym. Int. 2015, 64, 486-495. [CrossRef]

4. Liu, J.G.; Nakamura, Y.; Terraza, C.A.; Shibasaki, Y.; Ando, S.; Ueda, M. Highly Refractive Polyimides Derived from 2,8-Bis(p-aminophenylenesulfanyl)dibenzothiophene and Aromatic Dianhydrides. Macromol. Chem. Phys. 2008, 209, 195-203. [CrossRef]

5. Javadi, A.; Shockravi, A.; Koohgard, M.; Malek, A.; Shourkaei, F.A.; Ando, S. Nitro-substituted polyamides: A new class of transparent and highly refractive materials. Eur. Polym. J. 2015, 66, 328-341. [CrossRef]

6. Chan, H.S.O.; Ng, S.C. Synthesis, characterization and applications of thiophene-based functional polymers. Prog. Polym. Sci. 1998, 23, 1167-1231. [CrossRef]

7. Zotti, G.; Marin, R.A.; Gallazzi, M.C. Electrochemical Polymerization of Mixed Alkyl-Alkoxybithiophenes and -terthiophenes. Substitution-Driven Polymerization from Thiophene Hexamers to Long-Chain Polymers. Chem. Mater. 1997, 9, 2945-2950. [CrossRef]

8. Hosseini, S.H.; Entezami, A. Chemical and electrochemical synthesis of homopolymer and copolymers of 3-methoxyethoxythiophene with aniline, thiophene and pyrrole for studies of their gas and vapour sensing. Polym. Adv. Technol. 2001, 12, 524-534. [CrossRef]

9. Roux, C.; Leclerc, M. Rod-to-coil transition in alkoxy-substituted polythiophenes. Macromolecules 1992, 25, 2141-2144. [CrossRef]

10. Lévesque, I.; Leclerc, M. Ionochromic and Thermochromic Phenomena in a Regioregular Polythiophene Derivative Bearing Oligo(oxyethylene) Side Chains. Chem. Mater. 1996, 8, 2843-2849. [CrossRef]

11. Levésque, I.; Bazinet, P.; Roovers, J. Optical Properties and Dual Electrical and Ionic Conductivity in Poly(3-methylhexa(oxyethylene)oxy-4-methylthiophene). Macromolecules 2000, 33, 2952-2957. [CrossRef]

12. Marsella, M.J.; Swager, T.M. Designing Conducting Polymer-Based Sensors: Selective Ionochromic Response in Crown Ether Containing Polythiophenes. J. Am. Chem. Soc. 1993, 115, 12214-12215. [CrossRef]

13. Lévesque, I.; Leclerc, M. Novel Dual Photochromism in Polythiophene Derivatives. Macromolecules 1997, 30 , 4347-4352. [CrossRef]

14. Yoshino, K.; Nakajima, S.; Onada, M.; Sugimoto, R. Electrical and optical properties of poly(3-alkylthiophene). Synth. Met. 1989, 28, 349-357. [CrossRef]

15. Kumpumbu-Kalemba, L.; Leclerc, M. Electrochemical characterization of monolayers of a biotinylated polythiophene: Towards the development of polymeric biosensors. Chem. Commun. 2000, 1847-1848. [CrossRef]

16. Raymond, F.; di Césare, N.; Belletéte, M.; Durocher, G.; Leclerc, M. Molecular Design of a Thermochromic Polythiophene Derivative. Adv. Mater. 1998, 10, 599-602. [CrossRef]

17. Zhou, E.; He, C.; Tan, Z.; Yang, C.; Li, Y. Synthesis and properties of polythiophenes with conjugated side-chains containing carbon-carbon double and triple bonds. J. Polym. Sci. A 2006, 44, 4916-4922. [CrossRef]

18. Perepichka, I.F.; Perepichka, D.F.; Meng, H.; Wudl, F. Light-Emitting Polythiophenes. Adv. Mater. 2005, 17, 2281-2305. [CrossRef]

19. Tanaka, F.; Kawai, T.; Kojima, S.; Yoshino, K. Electrical and optical properties of poly(3-alkoxythiophene) and their application for gas sensor. Synth. Met. 1999, 102, 1358-1359. [CrossRef] 
20. Rella, R.; Siciliano, P.; Quaranta, F.; Primo, T.; Valli, L.; Schenetti, L.; Mucci, A.; Iarossi, D. Gas sensing measurements and analysis of the optical properties of poly[3-(butylthio)thiophene] Langmuir-Blodgett films. Sens. Actuators 2000, 68, 203-209. [CrossRef]

21. Rella, R.; Siciliano, P.; Quaranta, F.; Primo, T.; Valli, L.; Schenetti, L. Poly[3-(butylthio)thiophene] Langmuir-Blodgett films as selective solid state chemiresistors for nitrogen dioxide. Colloids Surf. A Physicochem. Eng. Aspects 2002, 198-200, 829-833. [CrossRef]

22. Rivers, T.J.; Hudson, T.W.; Schmidt, C. Synthesis of a Novel, Biodegradable Electrically Conducting Polymer for Biomedical Applications. Adv. Funct. Mater. 2002, 12, 33-37. [CrossRef]

23. Mousavi, Z.; Bobacka, J.; Ivaska, A. Potentiometric $\mathrm{Ag}^{+}$Sensors Based on Conducting Polymers: A Comparison between Poly(3,4-ethylenedioxythiophene) and Polypyrrole Doped with Sulfonated Calixarenes. Electroanalysis 2005, 17, 1609-1615. [CrossRef]

24. Tang, Y.; He, F.; Yu, M.; Feng, F.; An, L.; Sun, H.; Wang, S.; Li, Y.; Zhu, D. A Reversible and Highly Selective Fluorescent Sensor for Mercury(II) Using Poly(thiophene)s that Contain Thymine Moieties. Macromol. Rapid Commun. 2006, 27, 389-392. [CrossRef]

25. Pandey, P.C.; Upadhyay, S.; Singh, G.; Prakash, R.; Srivastava, R.C.; Seth, P.K. A New Solid-State pH Sensor and its Application in the Construction of All Solid-State Urea Biosensor. Electroanalysis 2000, 12, 517-521. [CrossRef]

26. Singhal, R.; Takashima, K.; Kaneto, K.; Samanta, S.B.; Annapoorni, S.; Malhotra, B.D. Langmuir-Blodgett films of poly (3-dodecyl thiophene) for application to glucose biosensor. Sens. Actuators 2002, 86, 42-48. [CrossRef]

27. Singhal, R.; Chaubey, A.; Kaneto, K.; Takashima, W.; Malhotra, B.D. Poly-3-hexyl thiophene Langmuir-Blodgett films for application to glucose biosensor. Biotechnol. Bioeng. 2004, 85, 277-282. [CrossRef] [PubMed]

28. Béra-Abérem, M.; Ho, H.A.; Leclerc, M. Functional Polythiophenes as Optical Chemo and Biosensors. Tetrahedron 2004, 60, 11169-11173. [CrossRef]

29. Almeida, S.; Rivera, E.; Reyna-Gonzalez, J.M.; Huerta, G.; Tapia, F.; Aguilar-Martínez, M. Synthesis and characterization of novel polythiophenes bearing oligo(ethylene glycol) spacers and crown ethers. Synth. Met. 2009, 159, 1215-1223. [CrossRef]

30. Tapia, F.; Reyna-González, J.M.; Huerta, G.; Almeida, S.; Rivera, E. Synthesis and characterization of novel polythiophenes bearing oligo(ethylene glycol) segments and azobenzene units. Polym. Bull. 2010, 64, 581-594. [CrossRef]

31. Aguilar-Ortiz, E.; Zaragoza-Galán, G.; Rein, R.; Solladié, N.; Aguilar-Martinez, M.; Macías-Ruvalcaba, N.; Rivera, E. Preparation and characterization of novel polythiophenes bearing oligo(ethylene glycol) spacers and porphyrin units: Optical and electrochemical properties. Synth. Met. 2012, 162, 1000-1009. [CrossRef]

32. Winnik, F.M. Photophysics of preassociated pyrenes in aqueous polymer solutions and in other organized media. Chem. Rev. 1993, 93, 587-614. [CrossRef]

33. Rivera, E.; Belletête, M.; Zhu, X.X.; Durocher, G.; Giasson, R. Novel polyacetylenes containing pendant 1-pyrenyl groups: Synthesis, characterization, and thermal and optical properties. Polymer 2002, 43. [CrossRef]

34. Rivera, E.; Wang, R.; Zhu, X.X.; Zargarian, D.; Giasson, R. Preparation of cis-poly(1-ethynylpyrene) using (1-Me-indenyl)(PPh3)Ni-C $\equiv \mathrm{C}-\mathrm{Ph} /$ methylaluminoxane as catalyst. J. Mol. Catal. 2003, 204, 325-332. [CrossRef]

35. Belletête, M.; Rivera, E.; Giasson, R.; Zhu, X.X.; Durocher, G. UV-Vis and fluorescence study of polyacetylenes with pendant 1-pyrenyl groups: A comparative investigation of cis-and trans-poly (1-ethynyl-pyrene). Synth. Met. 2004, 14, 37-42. [CrossRef]

36. Rivera, E.; Aguilar-Martínez, M.; Terán, G.; Flores, R.F.; Bautista-Martínez, J.A. Thermal, optical, electrochemical properties and conductivity of trans-and cis-poly (1-ethynylpyrene): A comparative investigation. Polymer 2005, 46, 4789-4798. [CrossRef]

37. Morales-Saavedra, O.; Rivera, E. Linear and nonlinear optical properties of trans-and cis-poly (1-ethynylpyrene) based sonogel hybrid materials. Polymer 2006, 47, 5330-5337. [CrossRef]

38. Morales-Espinoza, E.G.; Aguilar-Ortíz, E.; Vázquez-Arce, A.; Vázquez-Torres, H.; Rodriguez-Alba, E.; Rivera, E. Synthesis and characterization of novel luminescent polythiophenes containing pyrene units and oligo (ethylene glycol) spacers: Thermal and optical properties. Synth. Met. 2015, 199, 223-231. [CrossRef] 
39. Rodriguez-Alba, E.; Ortíz-Palacios, J.; Morales-Espinoza, E.G.; Vonlanthen, M.; Valderrama, B.X.; Rivera, E. Synthesis, characterization and optical properties of novel oligothiophenes bearing pyrene units attached via well defined oligo(ethylene glycol) spacers. Synth. Met. 2015, 206, 92-105. [CrossRef]

40. Farcas, A.; Jarroux, N.; Ghosh, I.; Guégan, P.; Nau, W.M.; Harabagiu, V. Polyrotaxanes of Pyrene-Triazole Conjugated Azomethine and $\alpha$-Cyclodextrin with High Fluorescence Properties. Macromol. Chem. Phys. 2009, 210, 1440-1449. [CrossRef]

41. Müllen, K.; Wegner, G. Electronic Materials: The Oligomeric Approach; Wiley-VCH: Weinheim, Germany, 1998.

42. Fichou, D. Handbook of Oligo and Polythiophenes; Wiley-VCH: Weinheim, Germany, 1999.

43. Otsubo, T.; Aso, Y.; Takimiya, K. Functional oligothiophenes as advanced molecular electronic materials. J. Mater. Chem. 2002, 12, 2565-2575. [CrossRef]

44. Acharya, A.; Mishra, R.; Roy, G.S. Characterization of CdSe/Polythiophene nanocomposite by TGA/DTA, XRD, UV-VIS Spectroscopy, SEM-EDXA and FTIR. Armen. J. Phys. 2010, 3, 195-202.

45. Bachman, J.C.; Kavian, R.; Graham, D.J.; Young Kim, D.; Noda, S.; Nocera, D.G.; Shao-Horn, Y.; Woo Lee, S. Electrochemical polymerization of pyrene derivatives on functionalized carbon nanotubes for pseudocapacitive electrodes. Nat. Commun. 2015, 6. [CrossRef] [PubMed]

46. Aguilar-Martínez, M.; Bautista Martínez, J.A.; Rivera, E. Thermal, Optical, Electrochemical Properties and conductivity of Pyrene Monomers. Des. Mon. Polym. 2008, 11, 173-178. [CrossRef]

47. Lakowicz, J.R. Principles of Fluorescence Spectroscopy, 3rd ed.; Springer: New York, NY, USA, 2006.

Sample Availability: Not available.

(C) 2016 by the authors; licensee MDPI, Basel, Switzerland. This article is an open access article distributed under the terms and conditions of the Creative Commons by Attribution (CC-BY) license (http://creativecommons.org/licenses/by/4.0/). 